\title{
The Role of Lampung Provincial Government in Controlling Plastic Waste Disposal Land
}

\author{
Widya Krulinasari $^{1^{*}}$, Tia Mayang Tika ${ }^{2}$ \\ Fakultas Hukum, Universitas Lampung, Bandar Lampung ${ }^{1,2}$ \\ $\underline{\text { widya.krulinasari@fh.unila.ac.id }}{ }^{1 *}$, sri.lestari1521@students.unila.ac.id $^{2}$
}

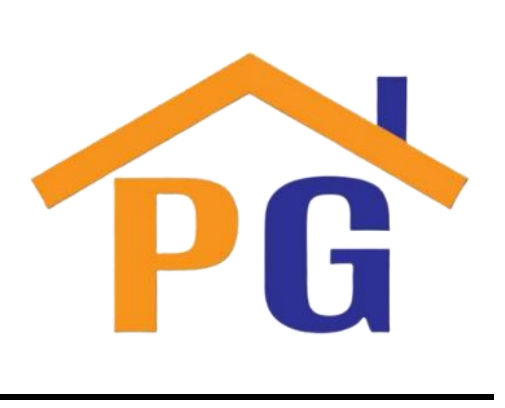

Riwayat Artikel

Received on pada 8 May 2021

Revised on 16 June 2021

Accepted on pada 2 July 2021

\begin{abstract}
Purpose: Plastic waste is a major threat to the environment, and the growing amount of plastic waste, particularly during the Covid-19 pandemic that has been ravaging Indonesia since the beginning of 2020, has compelled the government to implement a variety of measures to rein in the surge in plastic waste, including paying close attention to land designated for plastic waste disposal. Since 2019, residents of Lampung Province have generated more than 7,000 tons of waste per day. To ascertain the Lampung Provincial government's role in controlling land for plastic waste disposal, it is necessary to conduct this study.
\end{abstract}

Research Methodology: The research method used in this study is qualitative, and the data collection method is secondary.

Results: It can be concluded that the Lampung Provincial government is continuing to work on developing a system for the management of plastic waste.

Keywords: Government, Plastic Waste Management, Role

How to cite: Krulinasari, W \& Tika, TM. (2021). The Role of Lampung Provincial Government in Controlling Plastic Waste Disposal Land. Jurnal Ilmiah Hukum dan Hak Asasi Manusia, 1(1), 21-26.

\section{Introduction}

Plastic waste is one of the environmental issues that are still difficult to handle properly. The increasing use of plastics is a consequence of the development of technology, industry, and the growing population. The increasing use of plastic materials is increasing in direct proportion to the increase in the amount of plastic waste produced. Waste management problems can be seen from several indicators, namely the high amount of waste produced, the level of waste management services is still low, landfills are limited in number, waste management institutions, and cost problems (Jukung Jurnal Teknik Lingkungan, 3 (1): 66-74, 2017 as quoted from Kardono, 2007:631). During the current Covid-19 pandemic, the amount of plastic waste soared. Indonesian Institute of Sciences (LIPI) revealed that the surge in plastic waste is due to many people who do shopping online, which is about $96 \%$ of online shopping packages use plastic. So with the number of people who do online shopping, automatic plastic waste production will continue to grow.

According to Widiyatmoko et al. (2016) in the Journal of Environmental Technology Vol. 7 No. 1, 2423), Plastic waste including non-organic waste that is not easily decomposed naturally. Currently, the total occurrence of plastic waste in Indonesia reaches 5.4 tons per year, which is $14 \%$ of the total amount of household waste. In 2020, Minister of Environment and Forestry (LHK) Siti Nurbaya Bakar admitted that waste production in Indonesia reached 67.8 million tons. That is, there are about 185,753 tons of garbage every day produced by 270 million people. A large amount of landfills has an impact also on the increasing number of plastic waste. Plastic waste production will potentially continue to grow in line with the increasing population growth in Lampung Province recorded in 2019 waste production of 7200 tons per day produced by 9 million people. The problem of plastic waste on the coast of Lampung Bay until now has not been resolved. The volume of garbage in the waters of Lampung Bay continues to increase, especially in the rainy season where the garbage is carried by the river flow in the city when it rains. As a result, the activities of fishers around the waters became disrupted. The danger of plastic 
waste is because it has difficulty degrading properties (non-biodegradable). Research reveals that it takes 50-100 years for plastic waste to decompose perfectly. With the large number of plastic waste piles that are increasing day by day, this will have a negative impact on environmental pollution and human health if not handled properly.

Based on the description above, then the question arises, what is the role of the Lampung provincial government in controlling land for plastic waste disposal? So, it is necessary to do research to find out how the role of the Lampung provincial government in controlling plastic waste disposal land in Lampung Province.

This research aims to find out the role of the government of Lampung Province in the control of plastic waste disposal land. The research method used in this study is the qualitative research method. The purpose of qualitative research is to find answers to a phenomenon or question through the systematic application of scientific procedures using qualitative approaches (https://www.gurupendidikan.co.id/metode-penelitian-kualitatif/ as quoted from Yusuf, 2013:334)

\section{Discussion}

\section{Understanding Role}

The role comes from the word role, according to the Great Dictionary of Indonesian Language (KKBI) is interpreted as a player. The role is a dynamic aspect of position (status). When a person performs his rights and obligations in accordance with his position, he performs a role (Journal of the Department of Government Sciences Vol. 1 No. 1, 2018 as quoted from Soekanto, 2006:212). The role of causing a person to some extent can foresee the deeds of others. Roles are governed by prevailing norms. More roles point to function, self-adjustment, and as a process.

\section{Understanding Government}

Government in a narrow sense only includes institutions that take care of the implementation of the wheel of government (called executive), while the government in a broad sense other than the executive including institutions that comply with the legislation (called legislative) and that carry out the judiciary (called the judiciary). The government is an organization of the state that shows and exercises its power. According to Law No. 18 of 2008 (hereinafter referred to as Law No. 18 of 2008) on Waste Management of Local Government is the Governor, Regent or Mayor, and Regional Devices an elements of local government organizers. In Law No. 18 of 2008, as stated in article 5, the Government and Local Government are tasked to ensure good waste management and environmental insight.

Garbage itself is divided into two types, namely organic and non-organic waste. Organic waste is a type of waste that is easy to decompose, while non-organic waste is complicated to decompose. There are even some types that take up to 500 years to decompose perfectly. Examples of organic waste are leftovers, rotting fruits, cartons, paper, cardboard, while examples of non-organic waste are aluminum, Styrofoam, glass paper, metal, plastic, glass, ceramics.

\section{Plastic}

Plastic is an organic material that has the ability to be formed into various forms when exposed to heat and pressure. Plastic can be formed bars, sheets, or blocks when in the form of products can be bottles, food wrappers, pipes, tableware, and others. The composition and material of plastics are polymers and other additives, and polymers are composed of monomers bound by chemical bond chains (Waste Management Information, 2004). In general, plastics have low-density properties; insulation to electricity; has varying mechanical strength; resistance to limited temperatures; resistance to chemicals varies (Article Design of Plastic Bottled Wastewater Packaging Equipment with Multilevel Filtration System, 2018 as quoted from Nasiri, 2004).

Plastics are categorized as flammable materials that can lead to the threat of land fires, especially forests, smoke produced from burning plastics containing various toxic substances such as Hydrogen Cyanide $(\mathrm{HCN})$ and Carbon Monoxide (CO). This makes plastic waste an air pollution absorber and long-term effects such as global warming. Plastics can be grouped into two types, namely thermoplastic and 
thermosetting. Thermoplastic is a plastic material that will melt and can be reshaped if heated at a specific temperature, while thermosetting is a type of plastic. If it has been formed, solid can not be liquefied again. Based on the properties of both, thermoplastics is a type of plastic that can be recycled.

\section{Landfill Waste}

A landfill (TPA) is a place where waste reaches the final stage in its management since the start of the source, collection, transfer/transportation, processing and disposal. LANDFILL is a place where garbage is isolated safely so as not to disrupt the surrounding environment. In other words, landfill is the last place of garbage disposal and the last place of waste processed to be later returned to nature.

Landfill conditions in Indonesia are still a place to throw garbage openly (Open Dumping) simply. Determination of landfill location in Indonesia is regulated in SNI-03-3241-1994. In addition to SNI there are several determining factors of landfill location, namely:

- Availability of land at least can be used for one year

- Soil and topographic conditions should in such a way as to guarantee the availability of soil to cover in large quantities

- Surface water hydrology, it is necessary to consider to know the direction of groundwater flow and its effect on the filling of surface water around the sanitary landfill

- Hydrological and hydrogeological conditions, which are quite decisive factors in the site selection process to avoid pollution of Lindi water and gas produced by waste

- Local environmental conditions, to avoid conflict with the surrounding community, as sanitary landfills should be kept away from residential areas

- The expected potential upon completion to ensure long-term land use

- Haul distance, considered as close as possible to the rise of waste in order to minimize operating costs.

\section{The Role of Lampung Provincial Government in Controlling Plastic Waste Land}

In Lampung Province, control in waste management is still being pursued by the government of Lampung Province. As an increasingly worrying waste management effort, the government of Lampung Province plans to build a regional landfill in the Kota Baru area that is expected to improve the quality of waste handling for 7 (seven) districts/cities, namely Bandar Lampung, Metro, Pesawaran, Pringsewu, South Lampung, Central Lampung, and East Lampung. According to Chusnunia Chalim, Vice Governor of Lampung revealed that the regional landfill would operate integrated with waste processing into electric energy that can reduce landfills by 1000 tons per day and generate $14 \mathrm{MW}$ of electricity B3 waste management installations will also be built. Based on plastic waste production and B3 data in Lampung Province currently reaches 80 tons per day.

The following data on landfills in Lampung Province:

Table 1. Landfills in Lampung Province

\begin{tabular}{|c|c|c|}
\hline \multirow{2}{*}{ Regency/City } & TPA Name & TPA Type \\
\hline \multirow{2}{*}{ Lampung Barat } & Bahway & Control Landfill \\
\cline { 2 - 3 } & Balik Bukit & Open Dumping \\
\hline \multirow{2}{*}{ Lampung Selatan } & Lubuk Kamal & Control Landfill \\
\cline { 2 - 3 } & Tanjung Baru & Open Dumping \\
\cline { 2 - 3 } & Natar & $\begin{array}{c}\text { Control Landfill (in } \\
\text { Progress) }\end{array}$ \\
\hline Lampung Utara & Alam Kari & Control Landfill \\
\hline Pesawaran & Gedong Tataan & Control Landfill \\
\hline Pringsewu & Bumi Arum & Control Landfill \\
\hline
\end{tabular}

2021 | Jurnal Ilmiah Hukum dan Hak Asasi Manusia (Jihham)/ Vol 1 No 1, 21-26 


\begin{tabular}{|c|c|c|}
\hline Tulang Bawang & Menggala & Control Landfill \\
\hline Tulang Bawang Barat & Lembu Kibang & Control Landfill \\
\hline Pesisir Barat & Krui & Control Landfill \\
\hline Metro & Karang Rejo & Control Landfill \\
\hline Way Kanan & Blambangan & Sanitary Landfill \\
\hline Lampung Tengah & Yukum & Open Dumping \\
\cline { 2 - 3 } & Bandar Jaya & Open Dumping \\
\hline Lampung Timur & Labuhan Maringgai & Open Dumping \\
\hline Mesuji & Simpang Pematang & Open Dumping \\
\hline Tanggamus & Kalimiring & $\begin{array}{c}\text { Sanitary Landfill (in } \\
\text { Progress) }\end{array}$ \\
\hline Bandar Lampung & Bakung & Open Dumping \\
\hline
\end{tabular}

According to the Lampung Provincial Environment Office data, landfills in Lampung Province still use the Open Dumping system where waste is simply dumped in a landfill without any treatment. The Open Dumping system is considered very disruptive to the environment. TPA operated by Open Dumping will produce byproducts in the form of methane gas and Lindi liquid. Lindi liquids affect underground water properties such as high concentrations of dissolved solids, electrical conductivity, hardness levels, chloride, COD, nitrates, and sulfates, and contain heavy metals, where their content tends to decrease after the rainy season and increase before the rainy season (Jukung Jurnal Teknik Lingkungan, 3 (1): 66-74, 2017 as quoted from Vasanthi et al., 2008:227). Lindi water produced by landfills is difficult to control so as not to pollute the environment despite making strong protection on landfills. This is an important reason to make a modeling of Lindi water seepage where the misplacement of landfill greatly affects the movement of Lindi water to the surroundings (Jukung Jurnal Teknik Lingkungan, 3 (1): 6674, 2017 Dang et al., 2009; Tsanis, 2003; Young et al., 2003). Seeping Lindi water into the ground can contaminate the surrounding water bodies (Jukung Jurnal Teknik Lingkungan, 3 (1): 66-74, 2017 Cumar and Nagaraja, 2010; Kale et al., 2009), which will then affect exposed living things.

The government has issued a rule of Law No. 18 of 2008 on Waste Management that regulates waste management related to changes in the paradigm of waste management, division of authority and its implementation. A new and sustainable paradigm in terms of waste management is carried out with waste reduction and handling activities. The waste reduction includes restriction activities, reuse, and recycling, while waste handling activities include sorting, collection, transportation, processing, and final processing. This law mandates that all City/District Governments that still use TPA in the Open Dumping method must plan closures no later than a year from enacting the law.

Then sanitary landfill system is a waste management system by dumping and cultivating waste to a sunken location, compacting the waste and then closing it with soil; this method can eliminate air pollution. A Sanitary Landfill system is helpful to reduce the smell of rotting garbage in the soil. This technique also inhibits the waste of methane gas into the air that is the source of the smell of the rotting waste.

A controlled Landfill system is a waste management system that is almost the same as a sanitary landfill system where garbage is flattened on site and carried out periodic control. In Bandar Lampung city, TPA Bakung is the only main terminal in Bandar Lampung that holds all the garbage from Bandar Lampung city. In order to overcome the waste in Bandar Lampung, the Bandar Lampung City Government will cooperate with PT. Wijaya Karya (SOE) and Sumatra Institute of Technology to 
process raw landfill waste into power plant energy or Waste To Energy (WTE). While landfill in Metro City covering an area of 7 hectares has been utilized as an active cell of the landfill, the remaining land as a reserve if there is further TPA development. The Director-General of Hazardous and Toxic Waste Management plans in 2021 to provide support for constructing a Recycling Center (PDU) with a capacity of 50 Tons/day in Karang Rejo, Metro, Lampung. As an alternative to processing, recycle utilizes inorganic waste, and this process actually only delays or prevents inorganic waste material from accumulating in landfill

\section{Conclusion}

The application of the Open Dumping System is no longer justified in light of the potential negative impacts on the environment, as stated in Law No. 18 of 2008 on Waste Management, which requires the elimination of the Open Dumping System in Final Waste Processing. Although open dumping continues to be used in several landfills in Lampung Province, the Lampung Provincial Government is working to improve the level of control over plastic waste disposal land by gradually developing waste management systems in several landfills Lampung Province for more efficient utilization. Such as the use of Sanitary Landfill and Controlled Landfill systems, the development of waste management cooperation, and the development of landfill reserves.

\section{References}

2021. "Berita FGD Pembangunan TPA Regional Lampung Dan Pengelolaan Sampah Pesisir" http://bappeda.lampungprov.go.id/berita-fgd-pembangunan-tpa- $\quad$ regional-lampung-danpengelolaan-sampah-pesisir.html, diakses pada 5 Mei 2021.

2021. "Wakil Gubernur Lampung Canangkan Aksi Peduli Sampah Serentak Se- Provinsi Lampung", https://www.lampungprov.go.id/detail-post/wakil-gubernur- $\quad$ lampung-canangkan-aksipeduli-sampah-serentak-se-provinsi-lampung, diakses pada 4 Mei 2021.

Al Faqir, Anisyah. 2021. "LIPI: Jumlah Sampah Plastik Melonjak Selama Pandemi Covid-19", https://www.liputan6.com/bisnis/read/4454386/lipi-jumlah- $\quad$ sampah-plastik-melonjakselama-pandemi-covid-19, diakses pada 3 Mei 2021.

Anjelina Markus., Herman Nayoan., \& Stefanus Sampe. (2018). Peranan Lembaga Adat dalam Menjaga Keamanan dan Ketertiban Masyarakat di Desa Salurang Kecamatan Tabukan Selatan Tengah Kepulauan Sangihe. Jurnal Jurusan Hukum Pemerintahn, 1(1).

Daniel Wiliam, M., Eko Budi, S. (2019). Penentuan Lokasi Tempat Pemrosesan Akhir (TPA) Sampah yang Ramah Lingkungan di Kabupaten Bekasi. Jurnal Teknik, 8(2).

E. Ariesta PP, dan H.B Wijawa. (2014). Partisipasi Masyarakat dalam Pengelolaan Daur Ulang Sampah di Kelurahan Tugurejo, Kecamatan Tugu, Kota Semarang. Teknik PWK,3(3), 382-391.

Karuniastuti, N. (2013). Bahaya plastik terhadap kesehatan dan lingkungan. Swara Patra, 3(1).

Mahyudin, R.P. (2010). Strategi Pengelolaan Sampah Berkelanjutan. Enviro Scientae, 10,33-40.

Mahyudin, Rizqi Putri. (2017). Kajian Permasalahan Pengelolaan Sampah dan Dampak Lingkungan di TPA (Tempat Pemrosesan Akhir). Jurnal Teknik Lingkungan, 3(1), 66-74.

Muhammad, Hiru. 2021. "Gubernur: Pemkot Agar Fokus Atasi Banjir dan Sampah", https://www.republika.co.id/berita/qq24i7380/gubernur-pemkot-agar- fokus-atasi-banjirdan-sampah, diakses pada 4 Mei 2021.

Murdaningsih, Dwi. 2019. "Produksi Sampah di Lampung Capai 7200 Ton Per Hari", https://nasional.republika.co.id/berita/pv1hk6368/produksi-sampah-di- lampung-capai7200-ton-per-hari, diakses pada 3 Mei 2021.

Purwaningrum, P. (2016). Upaya Mengurangi Timbulan Sampah Plastik di Lingkungan. JTL, 8(2).

Rizal, A. (2011). Analisis Pengelolaan Persampahan Perkotaan di Kelurahan Boya Kecamatan Banawa, Kabupaten Donggala. Jurnal SMARTek,9, 155-172.

Surjandari I., Hidayatno A., Supriatna A. (2009). Model Dinamis Pengelolaan Sampah untuk Mengurangi Beban Penumpukan. Jurnal Teknik Industri, 11(2), 134-147.

Susanti, S., Sugiyanta, I. G., \& Nugraheni, I. L. (2014). Tinjauan Geografis Tempat Pembuangan Akhir Sampah Bakung Kelurahan Bakung Tahun 2013.

Undang-Undang Nomor. 18 Tahun 2008 Tentang Pengelolaan Sampah.

Widiyatmoko, at, al. (2016). Analisis Karakteristik Sampah Plastik di Pemukiman Kecamatan Tebet dan 
Alternatif Pengolahannya. Jurnal Teknologi Lingkungan, 7(1), 24-33. 